VÍT BOČEK

Czech Academy of Sciences, Brno

vitbocek@gmail.com

\title{
THE ETYMOLOGY OF THE SLAVONIC NAME FOR ERMINE (MUSTELA ERMINEA) II: A NEW PROPOSAL ${ }^{1}$
}

Keywords: Slavonic etymology, ermine, ${ }^{\star}$ gornostajb ${ }^{*}$ gornostalb

\begin{abstract}
The author discusses possible motivations for naming the ermine in Slavonic, adopts and further elaborates on the etymology of Common Slavonic ${ }^{*}$ gornostajb/ ${ }^{*}$ gornostals given by Černych (< Indo-European ${ }^{\star} g^{u h}$ er- 'warm, hot; get warm'), which eventually leads to a new, alternative solution based on the connection with the Indo-European root *uerH- 'blacken, get/be black'.
\end{abstract}

\section{Motivations}

In the previous part of this paper, we have found that researchers tried to find a motivation for naming the ermine in Slavonic in the colour of its fur, in its stink, nose shape, and behaviour. Presumably, the first two motivations, the colour of the fur or the stink, are more probable because they are apparently the most conspicuous characteristics of this animal. I would subscribe to the colour, because that is quite frequent in Slavonic and other Indo-European words for animals of the family Mustelidae. In addition to the Germanic and Baltic names of ermine derived from Indo-European ${ }^{\star} k$ 'er- 'grey', mentioned in the section (1) of the first part of the paper, three other Common Slavonic words are often (though definitely not unanimously)

1 The paper was written with the support of a grant from the Czech Science Foundation (No. 13-17435S). I thank Christina Dejkova (Sofia) for helping me with a reference and Václav Blažek (Brno) for useful comments. 
explained as derived from a colour: ${ }^{\star} k u n a$ 'marten' ( $\sim$ Lithuanian kiaune, Latvian caūna, caūne, Old Prussian caune 'marten' < Indo-European * ${ }^{*} e u$ - 'to shine, gleam; light, bright', cf. Pokorny 1959-1969, 1: 594; for a discussion, see Havlová 2010: 140), ${ }^{*}$ lasica, ${ }^{\star}$ lasøka 'weasel' ( Latvian adjective luōss 'yellow with a grey tone'; for a discussion, see Havlová 2010: 142), and *jězvbcb 'badger' ( $<H_{2}$ eig'- 'to shine, gleam'; the designation would be due to white patches on the head and neck; for a discussion, see Havlová 2010: 137-138). Another word for ermine derived from a colour, this time white, is Old Prussian gaylux (< Old Prussian * gaila- 'white', cf. Mažiulis 2013: 205). Thus, Černych's (1993) connection of the Slavonic word for ermine with the root ${ }^{*} g^{\text {uh }}$ er- 'warm, hot; get warm' (cf. the section (4) of the first part of the paper) seems the most plausible.

\section{Elaborating on Černych's solution}

Formally, Černych's solution is without problems. In my view, however, the semantic part of Černych's explanation could be modified. The author presupposes the motivation by brown, flamelike colour of the ermine's summer fur. However, the IndoEuropean root ${ }^{*} g^{\text {uh }}$ er- allows for yet another colour, namely black ('warm, hot' $\rightarrow$ 'burn' $\rightarrow$ 'be burnt, charred' $\rightarrow$ 'be black'). With respect to this, I refer to a very characteristic feature of ermine fur that entirely escaped the attention of the researchers and proposers of the extant hypotheses. A typical attribute of the ermine's coat, distinguishing it from other members of the family Mustelidae, is the black colour of its tail-tip. Importantly, the tail-tip remains black permanently, while the rest of the fur changes seasonally: in winter the fur is all white; in summer it has various tones of brown on the back and head (cf. the motivation preferred by Černych), and white below. In my opinion, the stability of the tail-tip colour might have represented a good motivation for naming the animal.

\section{New proposal}

Apart from the root ${ }^{*} g^{\text {uh }} e r$ - 'warm, hot; get warm', another Indo-European root with similar semantics can perhaps be considered as a promising candidate: the IndoEuropean *uerH- 'to burn (up); to be burnt; to get $\rightarrow$ have a colour of something burnt $=$ to blacken $\rightarrow$ to be black' (see Pokorny 1959-1969, 1: 1166). In Slavonic and Baltic, the following words designating animals of dark or black colours were derived from this root with the $n$-suffix or extension: Common Slavonic masculine *vornø 'raven' (> Old Church Slavonic vranı, Bulgarian dialectal and Macedonian vran, Serbo-Croatian and Slovene vrân, Old Czech vran, Lower Sorbian wron, Polish obsolete and dialectal wron, Belorussian dialectal vóran, vóron, Ukrainian and Russian vóron Lithuanian var̃nas, Old Prussian warnis); from it, the feminine *vorna 'crow' $\leftarrow$ *'belonging to raven, similar to raven' was derived (> Bulgarian vrána, Macedonian vrana, Serbo-Croatian vräna, Slovene vrána, Slovak vrana, 
Czech vrána, Upper Sorbian wróna, Polabian vorno, Polish wrona, Belorussian varóna, Ukrainian and Russian voróna Lithuanian várna 'crow', Old Prussian warnis 'raven', warne 'crow', Latvian värna 'crow'); the Common Slavonic adjective *vornz 'black (mainly of horses)' (> Old Church Slavonic vranz, Bulgarian colloquial and Macedonian vran, Serbo-Croatian and obsolete Slovene vrân, Slovak and Czech vraný, Old Polish and obsolete wrony, Belorussian varaný, Ukrainian voronýj, Russian voronój). ${ }^{2}$ If Common Slavonic * gornostajb/* gornostalb 'ermine' should be added to this nest, a sporadic change of $v(u)>g$ must be assumed. Such a change is rare, but it is attested in other Slavonic words. Let us mention some examples. Perhaps not a change, but a variation of prothetic $g \sim v$ before the nasal vowel $Q$ is often presupposed in the following two Common Slavonic

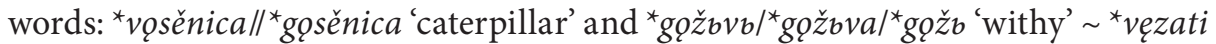
'to tie', ${ }^{\star} Q z z k z$ 'narrow', etc. (cf. Čalăkov 1968; recently Lekova 2006; for competing explanations, see ESJS, 4: 196; 10: 614 and 620-621). The sporadic change of $v>g$ is attested in individual Slavonic languages word-initially as well as wordinternally: cf. Kashubian and Slovincian gdova 'widow', gdovc 'widower' < Common Slavonic ${ }^{*} v b d o v a,{ }^{*} v b d o v b c b$ (Sychta 1967-1976, 1: 317; PW, 1: 207), Kashubian gröbel 'sparrow', Slovincian gröbäl 'sparrow' < Common Slavonic *vorbzl'b (Sychta 1967-1976, 1: 363; PW, 1: 233; cf. also Lorentz 1958-1962, 2: 589); dialectal Slovene zgûn 'bell' (< Common Slavonic *zvonz), zgor 'court, yard' $\left(<{ }^{*} d g o r<\right.$ Common Slavonic *dvorz; cf. Ramovš 1924: 160-161), dialectal Czech pohříslo < povř́slo 'straw binder' (Gebauer 1894-1929, 1: 431). Slightly different phenomenon, but still worth noting here, is the loss of $v$ in ${ }^{*} g v o-,{ }^{*} c h v o$ - clusters, as attested, for instance, in Serbo-Croatian dialectal gözd 'iron pole', Upper Sorbian hózdź 'nail, tack', Polish dialectal goźdź 'bung, spigot' (< Common Slavonic *gvozds 'nail', cf. ESJS, 4: 212, see also Schaarschmidt 1997: 129). ${ }^{3}$ The change of $v(u)>g$ is also known from other Indo-European languages. In Armenian, one of the three regular reflexes of Indo-European ${ }^{*} u$ is $g$, word-initially (Armenian get 'river' < Indo-European *ued-'water') as well as word-internally (see Schmitt 1981: 69-70). In Welsh and Breton, initial Indo-European $u$ changed to $g w$, cf., e.g., Breton and Welsh $g$ wir 'true' < Indo-European *uêro- 'true' (for a detailed analysis, see Jackson 1986: 427-473). The transition of $v(u)$ to $g$ is also attested word-initially as a kind of sound substitution in loanwords from one language to another. This phenomenon is well known from words of Germanic origin in Romance languages, cf. Gothic wadi 'guarantee' > French gage 'guarantee', Gothic walus 'staff, rod' > French gaule 'rod', Germanic *werra 'confusion, turmoil' > Italian guerra, French guerre 'war' (Meyer-Lübke 1935: 791, 793, 796; see also Čevelová, Blažek 20o9: 160-161). Similarly, prothetic $g$ - is added to English loanwords in Welsh (e.g., Welsh gwiced 'wicket, gate' < English wicket) or to French loanwords in Breton (e.g., Breton gwagen

2 For a thorough list of forms, other possible Indo-European cognates, and competing hypotheses concerning word formation relations (adjective > noun, or vice versa), see ESJS (18: 1081) with references.

3 Cf. also the change of preposition $v$ 'in, to' and prefix $v$ - to $(\gamma>) h / x$ in individual Slavonic languages or dialects (see Stanislav 1956-1973, 1: 537-538, with references). 
'wave' < English wave; see Parry-Williams 1913: 87-88). In Slavonic, a comparable substitution is attested in Czech hastrman 'water sprite' < Middle High German wazzerman 'a water monster' (Newerkla 2011: 175). The examples given above indicate that the shift under discussion can have two stages: (1) $v(u)>g^{u}$, (2) $g^{u}>g$. In some cases, only the first step has taken place, in others both of them. In fact, this development is more common than one would guess, as corroborated by other examples gathered by Kümmel in his typology of sound changes (see Kümmel 2007: 277, 378, 379, 381, 396, 400, 417 with references). Nevertheless, although the mentioned parallel developments affirm that the change is possible, we still have to explain, or at least suggest, why the change would happen in the Slavonic word for ermine and not in other words with initial $v$-, especially those of the same root ${ }^{*}$ uorn-, i.e., ${ }^{*}$ vorn 6 and ${ }^{*}$ vorna. A plausible explanation might be that the change occurred for taboo reasons. Within the family Mustelidae, the main "mighty animal" in the wider Indo-European context is the weasel (for an overview of its alleged negative and positive powers, see HDA, 9: 576-600; see also Havers 1946: 50-51). Among Slavonic peoples, however, the words for all members of the family Mustelidae display a great variety of symbolic meanings (for a detailed overview, see Gura 1997: 199-257 with specific passages on individual animals, including ermine). By and large, ermine plays an important role mainly in Slavonic chthonic and marriage symbolism (cf. SD, 1: 522). As always with this kind of data, it is hard to detect whether it reflects an ancient, Common Slavonic tradition, but the change in the beginning of the Slavonic word for ermine for taboo reasons cannot be excluded. Another, more prosaic explanation for the change would be a secondary influence of other words beginning with $g$-, or a sort of folk etymology.

Yet another connection of the Slavonic word for ermine with the root ${ }^{*} u e r H$ - is perhaps possible. Apart from ${ }^{\star} v o r n z$, the root is also present in another Common Slavonic word for raven, reconstructed as ${ }^{\star} g a-v o r n z$ (> Bulgarian gávran, Macedonian gavran, Serbo-Croatian gävrān, Slovene gâvran, Slovak and Czech havran, Upper Sorbian hawron, Lower Sorbian and Polish gawron, Belorussian hájvoron, Ukrainian havrán, hájvoron, dialectal Russian gájvoron). Here, we have *ga- of uncertain origin. Mostly, it is seen as an onomatopoeic interjection or expressive prefix, possibly a variant of ${ }^{*} k a$ - with counterparts in Baltic (cf., e.g., ESSJ, 6: 88-89; SP, 7: 74-76 with further references). It is possible only to speculate that the Slavonic word for ermine might also have contained this segment. If it did, ${ }^{*}$ ga-vorno-stajo could have undergone the process of shortening -avo- $>o$ in rapid speech. However, this solution is far too much "Machekian" and I would prefer the previous explanation with the alleged change of $v>g$.

As far as the second part of the Slavonic compound is concerned, I agree with Železnjak's (1995) interpretation (cf. Boček 2018) that -stajb ( $<{ }^{*}$ stati) meant 'state, essence in general'. Altogether, the original Common Slavonic ${ }^{\star}$ vorno-stajb $\left({ }^{*}\right.$ vornostalb) would mean 'always black', in the sense 'an animal with a black tail-tip', i.e. 'an animal whose tail-tip remains permanently black'. 


\section{Conclusion}

To conclude, the proposed etymology has good semantic grounds. It is less plausible formally because of the assumed sporadic change or shortening. Thus, the explanation is perhaps not better than the traditional ones, but rather equal to them. I offer it as a new alternative alongside the most probable solution given by Černych.

\section{References}

Boček V. 2018. The etymology of the Slavonic name for ermine (Mustela erminea) I: Material and existing theories. - SLing 135: 161-170.

Čalăkov M. 1968. Načalnoto konsonantno reduvane $g$ - : v- v slavjanskite ezici. - Andrejčin L.D. (ed.). Slavističen sbornik. Po slučaj VI Meždunaroden kongres na slavistite v Praga. Sofija: 19-29.

Černych P.Ja. 1993. Istoriko-etimologičeskij slovar' sovremennogo russkogo jazyka. [2 vols.]. Moskva.

Čevelová D., Blažek V. 2009. Gothic loans in Romance languages. - Linguistica Brunensia 57: 143-167.

ESJS = Erhart A., Havlová E., Janyšková I. (eds.). 1989-2016. Etymologický slovník jazyka staroslověnského. [18 vols.]. Praha, Brno.

Gebauer J. 1894-1929. Historická mluvnice jazyka českého. [4 vols.]. Praha.

Gura A.V. 1997. Simvolika životnych v slavjanskoj narodnoj tradicii. Moskva.

Havers W. 1946. Neuere Literatur zum Sprachtabu. Wien.

Havlová E. 2010. České názvy savcü. Praha.

HDA = Hoffmann-Krayer E., Bächtold-Stäubli H. (eds.). 1927-1942. Handwörterbuch des deutschen Aberglaubens. [10 vols.]. Berlin, Leipzig.

Jackson K.H. 1986. A historical phonology of Breton. Dublin.

Kümmel M.J. 2007. Konsonantenwandel. Bausteine zu einer Typologie des Lautwandels und ihre Konsequenzen für die vergleichende Rekonstruktion. Wiesbaden.

Lekova T. 2006. Fonetična variativnost pri nazvanijata na njakoi životni (po danii ot južnoslavjanskata knižnina ot XV-XVII vek). - Janyšková I., Karlíková H. (eds.). Studia etymologica Brunensia 3. Sborník př́spěvků z mezinárodní vědecké konference Etymologické symposion Brno 2005. Praha: 163-179.

Lorentz F. 1958-1962. Gramatyka pomorska. [3 vols.]. Wrocław.

Mažiulis V. 2013. Prūsų kalbos etimologijos žodynas. Vilnius.

Meyer-Lübke W. 1935. Romanisches etymologisches Wörterbuch. Heidelberg.

Newerkla S.M. 2011. Sprachkontakte Deutsch - Tschechisch - Slowakisch. Wörterbuch der deutschen Lehnwörter im Tschechischen und Slowakischen: historische Entwicklung, Beleglage, bisherige und neue Deutungen. Frankfurt am Main.

Parry-Williams T.H. 1913. Some points of similarity in the phonology of Welsh and Breton. Paris.

Pokorny J. 1959-1969. Indogermanisches etymologisches Wörterbuch. [2 vols.]. Bern, München. PW = Lorentz F., Hinze F. (eds.). 1958-1983. Pomoranisches Wörterbuch. [5 vols.]. Berlin.

Ramovš F. 1924. Historična gramatika slovenskega jezika. II. Konzonantizem. Ljubljana.

Schaarschmidt G. 1997. A historical phonology of the Upper and Lower Sorbian languages. Heidelberg. 
Schmitt R. 1981. Grammatik des Klassisch-Armenischen mit Sprachvergleichenden Erläuterungen. Innsbruck.

SD = Tolstoj N.I. (ed.). 1995-2012. Slavjanskije drevnosti. Etnolingvističeskij slovar'. [5 vols.]. Moskva.

SP = Sławski F. (ed.). 1974-2001. Słownik prasłowiański. [8 vols.]. Wrocław, Warszawa, Kraków, Gdańsk.

Stanislav J. 1956-1973. Dejiny slovenského jazyka. [4 vols.]. Bratislava.

Sychta B. 1967-1976. Słownik gwar kaszubskich na tle kultury ludowej. [7 vols.]. Wrocław, Warszawa, Kraków, Gdańsk.

Železnjak I.M. 1995. Do etymolohiji slov. *gornostajb. - Movoznavstvo 1995.4-5: 56-63. 